to the knee was much swollen and extremely tender, with a llarge amount of extravasated blood pigment under the skin. The appearance was such as to suggest to one medical man who saw the patient that it was a case of sarcoma of the tibia. The limb was too tender to handle much, but it was soft and elastic and I felt no doubt of the existence of considerable periosteal hæmorrhage. There was also a blood extravasation in the left eyelid, which was swollen and purple. The gums were spongy but not actually bleeding. The child generally was extremely anæmic and sallow. The ends of the radii were thickened and the ribs showed beading. The diagnosis was made of scurvy rickets and a diet of fresh anboiled milk, raw meat-juice, a little mashed potato, and some lime-juice was ordered, with a small dose of iron as medicine. Immediate and rapid improvement resulted and the child has ever since been healthy.

The second patient, seen only a few weeks ago, was a child, twelve weeks old, who had been fed from birth on Food No.1. Up to the age of eight or nine weeks she had flourished exceedingly, gaining in weight half a pound a week. Then she bagan to lose colour and flesh and when I saw her she was intensely anæmic, of the lemon-yellow colour of pernicious anæmia, thin, and in a state of utter exhaustion. There were no actual hæmorrhages, but the medical attendant and $I$ both felt that this was an early stage of the same disease. The food was stopped and a mixture of milk, cream, water, and milk-sugar, directed to be surrounded by boiling water for five minutes only, given as the chief food; but an ounce of unboiled milk, suitably diluted, and half an ounce of raw meat juice were also ordered daily. The child is now doing well.

It is clear that chemical suitability, digestibility, and freedom from microbes are not the only essentials of a food, but that there is something in fresh food-call it the "antiscorbutic" quality or what you will-which infants and adults alike need. The exclusive use of "artificial" foods and of milk sterilised by prolonged boiling is rather to be deprecated by the medical profession instead of being preached, as is the fashion, to a public already inclined to run wild over the microbe scare. Pasteurisation of milk, or (what is practically much easier in the ordinary household) heating the milk in a vessel surrounded by boiling water for ten minutes is probably sufficient to stop the danger of bacterial infection except in special circumstances, such as epidemic summer diarrhœa or typhoid fever or cholera epidemics.

It is much to be desired that firms of the high standing of Messrs. Allen and Hanburys, who have devoted so much care to the preparation of "infants' foods," should add to their value and diminish their danger by issuing with their tins a caution as to the need for the addition of some fresh food substance to the dietary.

I am, Sirs, yours faithfully,

$$
\text { Nottingham, Oct. 28th, } 1899 . \quad \text { W. B. RANsom. }
$$

\section{THE LONDON AND COUNTIES MEDICAL PROTECTION SOCIETY, LIMITED, AND THE MEDICAL DEFENCE UNION, LIMITED.}

To the Editors of THE LANCET.

SiRs,-I am directed by the Council of the Medical Protection Society to make to you the following statement. The usual monthly meeting of the Council of the society was held this afternoon at its office at 12, New-court, Lincoln'sinn. 60 candidates were elected members of the society. $£ 400$ were set a-ide for investment in augmentation of the reserve fund of the society, which now amounts to $£ 1061$. The total outstanding claims against the society are under $£ 50$. On August 10th, 1899, a letter was sent by the Council of the Protection Society to the Council of the Medical Defence Union of which the following is a copy :-

Dear Dr. Bateman,-My Council by their unanimo'ss vote have instructed me to inform you that it is considered that it would be of material public advantage if an amalgamation of your society with mine could be accomplished.

$\mathrm{My}$ Council are willing to leave the whole terma upon which amalgamation shall be carried out to an arbitrator-say, a barrister of high standing approved of by both societies-or, failing agreement, by the President of the Incorporated Law Society.

The arbitrator to have placed before him the whole of the books of both societies, the lists of members, accounts; be to examine same and employ an accountant of his own selection for that purpose. The arbitrator then to prepare a scheme for amalgamation, each society undertaking to abide by and carry out the scheme recommended by the arbitrator and bearing equal share of the expenses.

I am, yours sincerely Signed) HuGH Woods.

A. G. Bateman, Esq., M.B., C.M., General Secretary,

The reply to that communication was received from the Medical Defence Union on Sept. 26th last and was to-day read to the Council of the Protection Society. It was in these words :-

Dear Dr. Woods,-Your letter dated August 10th, 1899, was duly brought before the Council of the Medical Defence Union on Thursday of the Council.

I am directed to inform you that the Council, having most carefully considered the proposals which your letter contains, regret they are unable to accede to the terms suggested.

$$
\text { I remain, yours truly, }
$$

$$
\text { A. GEORGE Bateiran, Gen. Sec. }
$$

As you, Sirs, have expressed in THE LANCET a wise and practical interest in the amalgamation of these two societies, the Council of the Protection Society think it right that the facts concerning the last attempt to bring about this union, so widely desired by the medical profession, should be fully laid before you. You have in THE LANCET stated with regard to the negotiations carried on for the purpose of bringing about the amalgamation in 1896 a decided view concerning their breakdown.

In THE LANCET of July 25th, 1896, 'you say: "For our own part we find the view of the London and Counties Medical Protection Society sound and the objection raised by the Medical Defence Union trivial and not very logical." So much for that attempt at amalgamation. In making to the Medical Defence Union the suggestions contained in the letter quoted above the Protection Society was actuated solely by a desire to bring about the amalgamation by means absolutely fair to both societies and which would give no improper advantage to either society in the carrying out of the details of the proposed amalgamation.

I am, Sirs, yours faithfully,

HuGH Woods, Hon. General Secretary.

Westbury, Hornsey-lane, Highgate, London, N. Oct. 31st, 1899 .

\section{THE ROYAL MINERAL WATER HOSPITAL, BATH.}

To the Editors of THE LANCET.

SIRS,-The report on the sanitary condition of Bath published in THE LANOET of Oct. 14th contains an indictment against the management of the Royal Mineral Water Hospital so serious that the committee feel that they would not be justified in allowing it to pass unnoticed.

When the older part of the institution was erected, nearly 160 years since, it stood on what was then fairly open ground, in close proximity to the hot mineral springs, which were then, as now, in the very centre of the city. The city has grown and the hospital has to a certain extent been surrounded by shops and other buildings, to its partial disadvantage as regards ventilation and other sanitary requirements, but not to the extent your article would lead one to believe. Although endeavours have on several occasions been made to secure a more eligible position this cannot be obtained within the limits to which the mineral waters can be conveyed, and to demolish the present building and erect another on the same site would entail too great a sacrifice of space, as no doubt the corporation would require the front of the building to be set back several feet to bring it in line with the new block. Placed in this dilemma the committee during the current year have had under consideration the best means of improving the existing arrangements and some months ago called in an eminent sanitary authority from London who, on visiting the hospital, made a very complete and exhaustive examination of the buildings with regard to their ventilation, drainage, \&c., and subsequently furnished a report containing several valuable recommendations. Plans of the proposed alterations have been already before him and approved. These when carried out will render the sanitary condition as good as the space will allow.

With regard to some of the details of your article, all of which it is impossible to take up in this letter, it must be remembered that this hospital is not an ordinary one for surgical and serious medical cases requiring the best sanitary and antiseptic kind of building which modern science can devise, but it is only for persons suffering from rheumatism 